\title{
THE ENDOWMENT CAMPAIGN
}

We are pleased to report that more than 400 ASA members have now given tax-deductible gifts to the ASA Endowment. Their generosity has been crucial as we near our first goal for the receipt of matching funds from the National Endowment for the Humanities - $\$ 40,000$ in donations by July 31, 1991.

President Martin A. Klein has written to all ASA members asking your support for the Endowment Campaign. Please give as much as you can, but most importantly, give something. In the next several months, members of the Board and the Association's Development Committee will be approaching foundations and individual donors. Our case will be strongest with potential donors if we can demonstrate that a large proportion of ASA members are supporting the campaign by making gifts.

As you consider your gift, remember that a lifetime membership is an excellent way to support the ASA and avoid the hassle of yearly dues payments. The $\$ 1200$ cost of the lifetime membership may be paid over a three-year period. The Association's accountant indicates that purchasers of lifetime memberships may consider $\$ 800$ of the fee a charitable contribution.

\section{LETTERS}

Because of space limitations, letters appearing here may be edited.

Dear Dr. Bay:

We are writing to you concerning our experiences with a volunteer program which sends recent university graduates to Kenya for year-long internships. Visions in Action places interns for an administrative fee. The interns are responsible for all costs incurred during their stay.

As the program's first participants, we - have been dissatisfied with it and would like to warn others against participating.

With our acceptance, we were prom. ised that internships had been arranged "for us in Kenya. But upon our arrival, we discovered that not only had the majority of internships not been arranged, but that Visions in Action was not a registered organization with the Kenyan government. In addition, the process of legal documentation necessary for us to volunteer in Kenya had not been undertaken.

Furthermore, we had to absorb costs which were not outlined in the initial literature.

We have seen few tangible benefits from the administrative fee and wanted to pass on this information to other prospective interns. Although this program promises a lot for a comparatively small amount of money, it has fallen far short of its obligations.

Theresa Sebik, for former Visions in Action Interns

Shaun Skelton, the Director of Visions in Action, writes in response.

I was surprised to see the letter from Theresa Sebik on the Visions in Action Urban Development Intern program, and feel compelled to correct a number of inaccuracies and misunderstandings expressed.

This past year, Visions in Action placed 14 interns in Nairobi, Kenya, with nonprofit development organizations, newspapers and magazines. Two were placed in short-term internships and 12 for a period of one year. Our long-term program consists of a one-month orientation emphasizing indigenous language training, followed by an 11-month internship. It is true that 3 of the 12 long-term interns left early - two because they chose to pursue other endeavors, and one because of a lack of money. It is also true that costs ran slightly over the advertised budget - the orientation was approximately $\$ 100$ more per person, due to the late cancellations of several interns, and we failed to inform the interns that they would have to pay $\$ 25$ for their pupil's visa while in country.

However, there are quite a few inaccuracies in Ms. Sebik's letter. It is not true that all interns are responsible for all the costs for the internship - fully one-half of the long-term interns received some type of housing stipend from their sponsoring organization - some even received more of a housing stipend than the cost of their rent. As well, the organization's administrative costs are largely underwritten through donations, so none of the interns pay all of their costs. As for the suggestion that internships be arranged ahead of time, we believe that since the interns must raise their own funds for the internship, that it is important to offer them maximum flexibility in choosing their own internship; as well, nonprofits rarely agree to accept a person on their staff for a year if they have never met them. We place an intern only after both the intern and the recipient organization are comfortable with each other.

In response to Ms. Sebik's concern that we are not a registered organization in Kenya, it is not a relevant point, since we place interns through our legal Kenyan counterpart, Kingozi/Interchange.

As Ms. Sebik correctly points out, we do offer much for a very reasonable cost. Our 1991-92 internships require interns to raise between $\$ 4200-5000$ for an entire year in an African city, including airfare, room and board, orientation, language training, health insurance and spending money. The interns in Ms. Sebik's group paid only a $\$ 200$ fee for administrative costs that ran to $\$ 1400$ per intern - thus, over $85 \%$ of the administrative costs of her internship were paid for through private donations.

Finally, as anyone who has worked for a while in Africa knows, there is much that happens there that is unpredictable, and running an intern program without a large financial base or upper level diplomatic connections, such as the Peace Corps has, is a very difficult task indeed. What Ms. Sebik does not seem to understand is that this was the first year we have run the program. Many of the initial problems have been worked out and will not inhibit future programs, and I thank her and all of the first year interns for providing important suggestions on how to improve the program. As we build this program throughout Africa's urban centers, their comments are all being taken into consideration. 
Dear Dr. Bay:

I read in the ASA News, January/March 1991, that the ASA Board has been discussing the issue of the academic boycott of South Africa. I have been in South Africa for a year, mainly doing research but also some teaching, and I would like to contribute some ideas to the debate.

There are two issues involved here. One is whether there are valid reasons for pursuing the boycott at this point. The second is one of academic freedom. I see no enthusiasm for the academic boycott here. "Progressive" South Africans have de facto called off their own boycott of the black universities - Transkei, Fort Hare, etc., having concluded that nothing was gained by leaving these institutions in reactionary hands. The international boycott of other institutions has a similar effect - only conservative visiting professors come and students only get exposed to certain ideas. However, it remains important for scholars to make sure they are not being used - there is a major difference between giving a lecture at a university, arranged through normal academic channels, and going on a government sponsored lecture tour. That, at least, has been my conclusion, and on that basis I have been teaching at Wits and I do not regret it.

My teaching was cleared with UDUSA, and I have serious doubts about that decision. Having been certified as sufficiently anti-apartheid to be fit to teach, I concluded this is a clear violation of academic freedom. Asking the blessing of UDUSA means in practice recognizing the principle that political beliefs are an acceptable criterium to be used in screening faculty. The fact that in this case the political belief is one we all share does not erase the problem.

$A S A$ News states that members of the Board of Directors suggested that scholars should visit South Africa only with the advance approval of UDUSA, or even the ANC, the UDF or mass democratic movement - the latter suggestion is based on a misunderstanding of what the mass democratic movement is, by the way; it is not an organization that could grant a permission. I strongly advise you to consider well the implications of these suggestions. It is extremely dangerous to establish the precedent that political organizations have the right to limit freedom of speech. It may be worth remembering too that the ANC is not the only party in South Africa, not even the only black party. Why not ask for the PAC's permission, or AZAPO's or, God forbid, Inkatha's?

If the ASA feels it is time to start lifting the academic boycott, it should consider offering guidelines to scholars about the kind of institutions and activities they should avoid, and conversely about what they could do which may be helpful in this difficult period of transition. But it should not suggest that political organizations have the right to approve or veto individuals on ideological grounds. Marina Ottaway University of the Witwatersrand

\section{Dear Dr. Bay:}

Martin Klein's "The ASA, Scholarly Research and South Africa" in the April/ June 1991 issue of ASA News is a disturbing piece. I do not for a moment doubt his intentions nor do I wish to question his integrity. But his misguided intervention does pose certain dangers for the liberation movement, for it favors the apartheid regime, at least in its practical import.

We can look at the issue he raises about dropping the academic boycott of South Africa another way. In 1986 at the ASA meeting in Madison, Wisconsin, a group of concerned scholars took a stand against the inclusion of a representative of Renamo on the same platform as two other scholars speaking to the situation in $\mathrm{Na}$ mibia and Uganda. The outraged members present staged a dignified walkout once they realized their quite unintended but obnoxious role in placing Renamo on the same respectable plane as SWAPO and the Ugandan Liberation Front. In their principled opposition to Renamo, there was no question of imposing any kind of "ideological controls over research" or "vetting scholarship." There is neither research nor scholarship worthy of emulation in contemplating mass murder and dressing up the evil in some pseudoacademic garb. In conferring some semblance of academic respectability to the Renamo representative's defense of the type of senseless carnage perpetrated by Renamo against the people of Mozambique, the ASA would have been hovering dangerously close to giving some legitimacy, however unwittingly, to the slaughter of the innocent, under the pretense that it was objectionable to "demand that other scholars take an ideological litmus test." The stand taken against Renamo was not merely ideological — though ideology was as important an ingredient in this in- stance as it was in the case of academics who stood up to Nazism - but it was also eminently humane. Their stand took in the good of humanity which they rightly saw as loftier than sanctioning evil dressed in academic robes.

The academic and cultural boycott, like sanctions against South Africa in general, was not championed by people with "ideological blinders," for the insidious purpose of preventing us from carrying out "our obligation ... to seek our truths wherever we find them." The boycott was undertaken to expose lies rather than to suppress the truth. There was a realization among those who saw apartheid, like Nazism, as a crime against humanity that at the heart of apartheid culture was an affront to humanity, especially that of the African people of South Africa. In a conflict with nobler claims of humanity, claims to life itself, the humane position to adopt was to uphold the primacy of humanity and the inviolable right of the downtrodden and oppressed to life. That is what the South African struggle, like the struggle in Mozambique, is still about.

The give-away sentence in Martin Klein's appeal to "objectivity" is the following statement, which confuses signal or symbol with substance: "South Africa is going through a rapid process of change." In whose estimate? Such an utterance is not the product of the "free exercise" of anyone's "critical faculties;" it has certain political ramifications and, in fact, reflects the point of view of the apartheid regime. "Apartheid is dead" has been their favorite utterance for more than a decade, but no one has as yet seen the corpse. If ASA wants to act on principles which uphold the primacy of life and freedom for all, it would be wise to await the verdict of the bereaved, in this case the victims of apartheid themselves, before donning mourning clothes to attend the funeral, or indulging in the kind of academic vulturism Martin Klein's statement propagates. Mbulelo Vizikhungo Mzamane University of Vermont

\section{Martin Klein responds:}

The difference between Professor Mzamane and myself is not over goals, but over how best to implement those goals. I believe not only in "life and freedom," but in equality and social justice. I have long been a member of a Toronto liberation support committee and have given money 
to the ANC. That does not mean that I must support everything the ANC does or do everything the ANC asks me to do.

I did not claim in my memo that apartheid was dead, only that rapid change is taking place. Mandela is free and the ANC is operating openly within South Africa. I am well aware that South Africa has a long way to go and that De Klerk will do his best to preserve some form of white hegemony. My memo, however, was not about politics, but about the way

\section{ANNUAL MEETING 1991}

The preliminary program for the 1991 ASA Annual Meeting will be mailed to ASA members in late July. Make your hotel and plane reservations early.

The Annual Meeting program begins on Saturday morning, November 23 and ends at Tuesday midday, November 26, two days before the Thanksgiving holiday. The airlines have assured us that all normal special fares are in effect for the week before Thanksgiving. However, good deals disappear quickly as people make plans for the holiday. Call Conventions in America (see ad this page) for travel assistance.

All sessions will take place at the Adam's Mark Hotel, Fourth and Chestnut, in downtown St. Louis. Reserve your room by calling 314-2417400 or ask Conventions in America to make your reservation for you. The single room rate is $\$ 72$ and double $\$ 79$.

Program Chair Victor Le Vine has planned an excellent program that features more than 160 panels on all aspects of African studies, a keynote address by Wole Soyinka and a special tribute and memorial to Gwendolyn Carter.

The ASA Women's Caucus will sponsor a mini-conference on "The Status of Women's Studies in Africa" on November 22-23. Women's Caucus members will receive further information on that event in the Women's Caucus newsletter. foreign scholars should relate to South Africa.

I do not believe that any of us is objective. That does not mean we should not try. I am a scholar. I believe that as scholars, we are most effective when beholden to no single group, when capable of questioning our friends and our most deeplyheld ideals. I also believe that the quest for truth and understanding has undermined and isolated the South African regime, largely because its social order of- fends our most profoundly held principles. Mzamane claims that "spurious claims to academic pursuit sometimes conflict with the nobler claims of humanity." In this, I would argue that academic research on South Africa has provided the basis for these nobler claims. In this case, as in most such cases, the restriction of the free inquiry and discussion of issues, whether self-imposed or imposed by higher authority, is dysfunctional for the very groups supporting it.

\section{African Studies Association 1991 ASA Annual Meeting November 23-26 - St. Louis, Missouri}

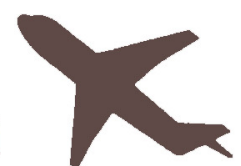

Get there for less! Call Conventions in America for lowest fares on any airline and discounts on Trans World Airlines and Alamo Rent-a-Car. Save time by requesting your hotel accommodations in advance at Adams Mark when purchasing airline tickets.

\section{Call 1-800-535-1492 - ASA acct. \#469: \\ ¿ Lowest fares on any airline (guaranteed at time of booking) \\ * Advance hotel request when purchasing airline tickets \\ * Discounted airfares on TWA (see below) \\ - Discounted car rental rates from Alamo Rent-A-Car (see below) \\ \% Free flight insurance of $\$ 100,000$ \\ क Senior Citizen discounts honored $(62 \&$ over $)$ \\ \% Frequent Flyer mileage \\ ⿷ Boarding passes \& seat assignments \\ ¿ Tickets mailed promptly upon receipt of payment \\ - Credit card, check, money order accepted.}

\section{Official Carrier: TWA* \\ $45 \%$ off unrestricted coach fares}

$5 \%$ off lowest applicable fares, from first class to the deeply discounted ultra-saver fares.

*7 day advance purchase \& some restrictions apply. Call 1-800-535-1492 - or if you call TWA directly @ 1-800-325-4933, you must refer to Profile \#CV10821, and ask to be ticketed by Conventions in America, the official agency of record, in order to receive additional free benefits. If you call Alamo directly @ 1-800-327-9633 refer to Code *75715, Rate Code G2.

Plus, you become eligible to win two free round trip tickets to any one of 150 destinations in the continental U.S. on selected carriers. Open to all passengers ticketed through Conventions in America.

\section{Call one number ... . 1-800-535-1492 ASA acct \#469}

Reservation hours: 7:00am-5:00pm PST ( $24 \mathrm{hr}$. information service available) Conventions in America, 7220 Trade St \#120, San Diego, CA 92121 - 619-566-0600/fax 619-566-7220 